\title{
Toxic effects of dietary hydrolysed lipids: an in vivo study on fish larvae
}

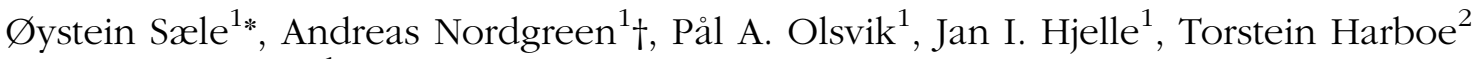 \\ and Kristin Hamre ${ }^{1}$ \\ ${ }^{1}$ National Institute of Nutrition and Seafood Research, PO Box 2029, Nordnes, 5817 Bergen, Norway \\ ${ }^{2}$ Institute of Marine Research, Austevoll, 5392 Storebø, Norway
}

(Submitted 16 January 2012 - Final revision received 12 April 2012 - Accepted 22 May 2012 - First published online 20 July 2012)

\begin{abstract}
We have previously described that fish larvae absorb a larger fraction of dietary monoacylglycerol than TAG. To investigate how dietary hydrolysed lipids affect a vertebrate at early life stages over time, we fed Atlantic cod (Gadus morhua) larvae six diets with different degrees of hydrolysed lipids for $30 \mathrm{~d}$. The different diets had no effect on growth, but there was a positive correlation between the level of hydrolysed lipids in the diets and mortality. Important genes in lipid metabolism, such as PPAR, farnesoid X receptor (FXR) and stearoyl-CoA desaturase $(S C D)$, were regulated by the different diets. Genes involved in the oxidative stress response did not respond to the increased lipid hydrolysation in the diets. However, enterocyte damage was observed in animals fed diets with $2.7 \%$ NEFA (diet 3 ) or more. It is thus possible that mortality was due to infections and/or osmotic stress due to the exposure of the subepithelial tissue. In contrast to earlier experiments showing a positive effect of dietary hydrolysed lipids, we have demonstrated a toxic effect of dietary NEFA on Atlantic cod larvae. Toxicity is not acute but needs time to accumulate.
\end{abstract}

Key words: Lipid nutrition: Early life stages: Intestinal damage: Oxidative stress: Lipase activity: Lipid metabolism

Lipids are a major source of metabolic energy, a source of essential fatty acids (FA) which are precursors of important signalling molecules, the eicosanoids, and are components of biological membranes ${ }^{(1)}$. Proper digestion and absorption of lipids in early life are therefore of vital importance. The digestion of lipids starts when fat is emulsified by bile acids to form micelles. Micelles increase the surface area of the lipids to make them available to digestive enzymes. Lipases, the common term for lipid-digesting enzymes, will then hydrolyse the ester bonds of the multitude of lipid classes including TAG, glycerophospholipids (PL) and wax esters. Some of the products from this digestion are NEFA, monoacylglycerol and lysophospholipids (lyso-PL), which are absorbed by the enterocytes together with bile ${ }^{(2)}$.

Lipid digestion in fish and mammals is very similar. The principal difference lies in how TAG is hydrolysed. The primary intestinal neutral lipase in mammals is pancreatic lipase functioning together with co-lipase ${ }^{(3)}$, while in teleost fish, carboxyl ester lipase, also called bile salt-activated lipase (BAL), has the same role ${ }^{(4,5)}$. Digestion of PL is similar in mammals and fish, where the principal enzyme secreted is phospholipase $\mathrm{A}_{2}\left(\mathrm{PLA}_{2}\right)$ group $\mathrm{IB}^{(6,7)}$.
Mammals are born with deficient or immature lipase production in the pancreas ${ }^{(8,9)}$. Similarly, teleost fish such as Atlantic cod (Gadus morbua) are hatched with a very low endogenous production of lipases ${ }^{(5,6,10)}$. The most important contributors to the digestion of neutral lipids in suckling mice are pancreatic lipase-related protein 2 (PLRP) produced in the pancreas by the suckling pup and BAL, delivered in the milk. PLRP-2 is a protein with high structural similarities to pancreatic lipase. Atlantic cod has a very low pancreatic production of BAL when it starts ingesting food 3-5 d after hatching ${ }^{(5)}$. Only one PLRP has been described in Atlantic cod, but it seems rather to be related to PLRP-1 than to PLRP-2 or pancreatic lipase ${ }^{(5)}$. In mammals, PLRP-1 is also produced in the pancreas and excreted in the intestine but it does not have lipolytic capabilities; its function is currently unknown. It is thus uncertain whether the teleost version of PLRP has any digestive function.

Another similarity between the suckling mammal and teleost larvae is that their food contains active lipases. BAL has been described in the milk of several mammals ${ }^{(11)}$. Fish larvae feed on rotifers and copepods which contain neutral lipases $^{(12)}$. There are contradictory findings as to whether

\footnotetext{
Abbreviations: BAL, bile salt-activated lipase; dph, day post-hatch; FA, fatty acid; PC, phosphatidylcholine; PE, phosphatidylethanolamine; PI, phosphatidylinositol; PL, glycerophospholipids; PLA 2 , phospholipase $\mathrm{A}_{2}$; PLRP, pancreatic lipase-related protein; PS, phosphatidylserine.
}

*Corresponding author: $\varnothing$. Sxle, fax +4755905299, email Oyse@nifes.no

† Present address: NOFIMA, Kjerreidviken 16, 5141 Fyllingsdalen, Norway. 


\section{Analysis of the prepared diets}

Crude protein $(\mathrm{N} \times 6.25)$ was determined by total combustion using a nitrogen analyser (Leco FP-528, Leco). Lipid class composition was analysed by high-performance thin layer chromatography analysis (Iatron Laboratories, Inc.), using the method described by Henderson \& Tocher ${ }^{(16)}$. Total lipid was estimated as total FA by analysing FA composition in total lipids with GLC according to Lie \& Lambertsen $^{(17)}$, using 19:0 as an internal standard. DM content of the diets was determined gravimetrically after drying for $24 \mathrm{~h}$ at $104^{\circ} \mathrm{C}$.

\section{Biological parameters}

The experiment was conducted in accordance with the Animal Welfare Act of 12 December 1974, no. 73, \$\$22 and 30, amended 19 June 2009. Cod eggs were collected from captive brood stock. Fertilised naturally spawned eggs were incubated and hatched in 70 litre tanks. The temperature in these units was similar to brood stock temperature, approximately $6^{\circ} \mathrm{C}$. The majority of the eggs were hatched after $15 \mathrm{~d}$ and then transferred to the first feeding tanks ( 400 litres, with central aeration). The tanks had $24 \mathrm{~h}$ light and the larvae were fed rotifers (Brachionus plicatilis) in meals. Green water was made by using algae paste. Continuous feeding was initiated $3 \mathrm{~d}$ after transfer to the feeding tanks. Water temperature was gradually raised from 6 to $12^{\circ} \mathrm{C}$ over $6 \mathrm{~d}$. At $30 \mathrm{~d}$ posthatch $(\mathrm{dph})$, the larvae were randomly distributed to eighteen 50 litre tanks, at the rate of 200 larvae in each tank. The larvae were only fed the trial diets from this point. The trial diets were fed in triplicate and the diets were assigned to the tanks in random order. The larvae were also in these tanks exposed to $24 \mathrm{~h}$ light. On each day, $10 \mathrm{ml}$ of feed were put on a belt feeder. In the beginning, additional hand feeding was done. The tanks were cleaned daily and water flow was increased during the experiment so that water oxygen content did not decrease below $80 \%$ saturation. Water temperature was maintained at $12 \pm 0.5^{\circ} \mathrm{C}$ throughout the experiment.

\section{Biological sampling}

Larvae were sampled at $45 \mathrm{dph}$, and at the end of the experiment at $60 \mathrm{dph}$. All larvae were anaesthetised with metacaine (MS-222 ${ }^{\mathrm{TM}}$; Norsk Medisinaldepot AS) and photographed, before euthanising with an overdose of metacaine. The larvae were pooled and snap-frozen in liquid $\mathrm{N}_{2}$ for lipid analysis, enzyme activity and RNA extractions. For histology, individual larvae were fixed in $4 \%$ paraformaldehyde buffered in PBS (pH 7.4) overnight.

\section{RNA extraction and quantitative $P C R$}

Frozen larvae were homogenised on Quiazol (Qiagen) using a Precellys 24 (Bertin Technologies). Total RNA was extracted from the whole fish on a Bio Robot EZ1 using the EZ1 RNA Universal Tissue Kit with the RNase-free DNase Set (Qiagen), according to the manufacturer's instructions. The quality of RNA was assessed with the NanoDrop ${ }^{\circledR}$ ND-1000 UV-Vis
Spectrophotometer (NanoDrop Technologies). For all total RNA samples, the optical density ratio at $260 / 280 \mathrm{~nm}$ ranged between 1.65 and $2 \cdot 11$.

Integrity of RNA was controlled in twelve randomly chosen samples out of the thirty-six using the Agilent 2100 Bioanalyzer and the RNA 6000 Nano LabChip ${ }^{\circledR}$ kit (Agilent Technologies). RNA integrity numbers ${ }^{(18,19)}$ were between $9 \cdot 0$ and 10 .

RT-PCR were run in duplicates on a ninety-six-well plate. For efficiency calculations, a two-fold serial dilution of total RNA, mixed from all samples, ranging from 1000 to $31 \mathrm{ng} / \mu \mathrm{l}$, was run in triplicates. All reactions were synthesised with a $500 \mathrm{ng}$ total RNA input. Each plate included a notemplate control and a RT control (a reaction without an RT enzyme). Plates were run on a GeneAmp PCR 9700 (Applied Biosystems) using the TaqMan Reverse Transcription Reagent containing Multiscribe Reverse transcriptase (833.5 nkat/ $\mu \mathrm{l}$ (50 U/ $\mu \mathrm{l})$; Applied Biosystems).

Reverse transcription was performed at $48^{\circ} \mathrm{C}$ for $60 \mathrm{~min}$ by using a oligo dT primers $(2 \cdot 5 \mu \mathrm{M})$ for all genes in $30 \mu \mathrm{l}$ total volume. The final concentrations of other chemicals in each RT reaction were as follows: $\mathrm{MgCl}_{2}$ (5.5 mm), deoxyribonucleotide triphosphate (500 mm of each), 10X TaqMan RT buffer $(1 \times)$, RNase inhibitor $(6.668 \mathrm{nkat} / \mu \mathrm{l}(0.4 \mathrm{U} / \mu \mathrm{l}))$ and multiscribe RT $(27.8389 \mathrm{nkat} / \mu \mathrm{l}(1.67 \mathrm{U} / \mu \mathrm{l}))$.

From each RT reaction, $2 \mu \mathrm{l}$ complementary DNA were pipetted in duplicates to 384-well plates, followed by $18 \mu \mathrm{l}$ consisting of $7.6 \mu \mathrm{l}$ double-distilled water, $10 \mu \mathrm{l}$ SYBR Green PCR Master Mix (Applied Biosystems) and $0.2 \mu \mathrm{l}$ of each primer $(50 \mu \mathrm{m}$ forward and reverse). Pipetting was done using a robot Biomek 3000 (Beckman Coulter). Real-time PCR was run on the LightCycler ${ }^{\circledR} 480$ Real-Time PCR System (Roche Applied Sciences), with a 5 min activation and a denaturing step at $95^{\circ} \mathrm{C}$, followed by forty cycles of a $15 \mathrm{~s}$ denaturing step at $95^{\circ} \mathrm{C}$, a $60 \mathrm{~s}$ annealing step and a $30 \mathrm{~s}$ synthesis step at $72^{\circ} \mathrm{C}$. The annealing temperature was $60^{\circ} \mathrm{C}$ for all primer pairs. Results were calculated as the arithmetic mean. Ribosomal protein L37, ubiquitin and elongation factor $1 \mathrm{~A}$ were selected as reference genes based on the study of Sæle et $a{ }^{(20)}$. The geNorm visual basic for applications applet for Microsoft Excel was used to determine a normalisation factor based on the reference genes ${ }^{(21)}$. Primer sequences, product size and PCR efficiency for each quantitative PCR assay are given together with the corresponding accession number in Table 3 .

\section{Lipase activity}

Whole larvae and dissected gastrointestinal tracts were homogenised in four times the sample wet weight of PBS with an Ultra-Turax ${ }^{\circledR} 20000$ (UpM, Janke u. Kunkel KG) followed by a second homogenisation in a ball mill (Retsch ${ }^{\circledR}$ MM301, Retsch), for $2 \times 2 \mathrm{~min}$ (thirty shakes/s). Homogenates were centrifuged at $10000 \mathrm{~g}$ for $15 \mathrm{~min}$ at $4{ }^{\circ} \mathrm{C}$ and supernatants used for enzyme activity were measured for total protein with the BCA Protein Assay Kit (Thermo Fisher Scientific, Inc.) according to the manufacturer's instructions.

Neutral lipase activity measurements were based on Murray et al. ${ }^{(22)}$, with modifications according to Sæle et al. ${ }^{(5)}$. 


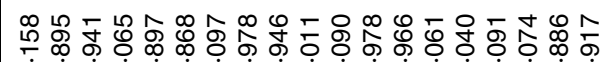
$\dot{\sim} \dot{\sim} \dot{\sim} \dot{\sim} \dot{\sim} \dot{\sim} \dot{\sim} \dot{\sim} \dot{\sim} \dot{\sim} \dot{\sim} \dot{\sim} \dot{\sim} \dot{\sim} \dot{\sim} \dot{\sim} \dot{\sim} \dot{\sim} \dot{\varphi}$

व

온 क

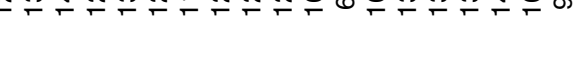

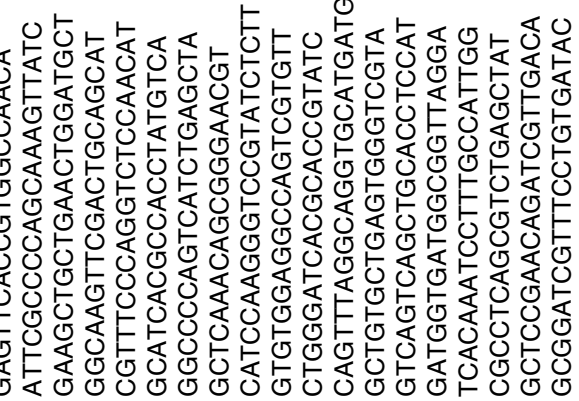
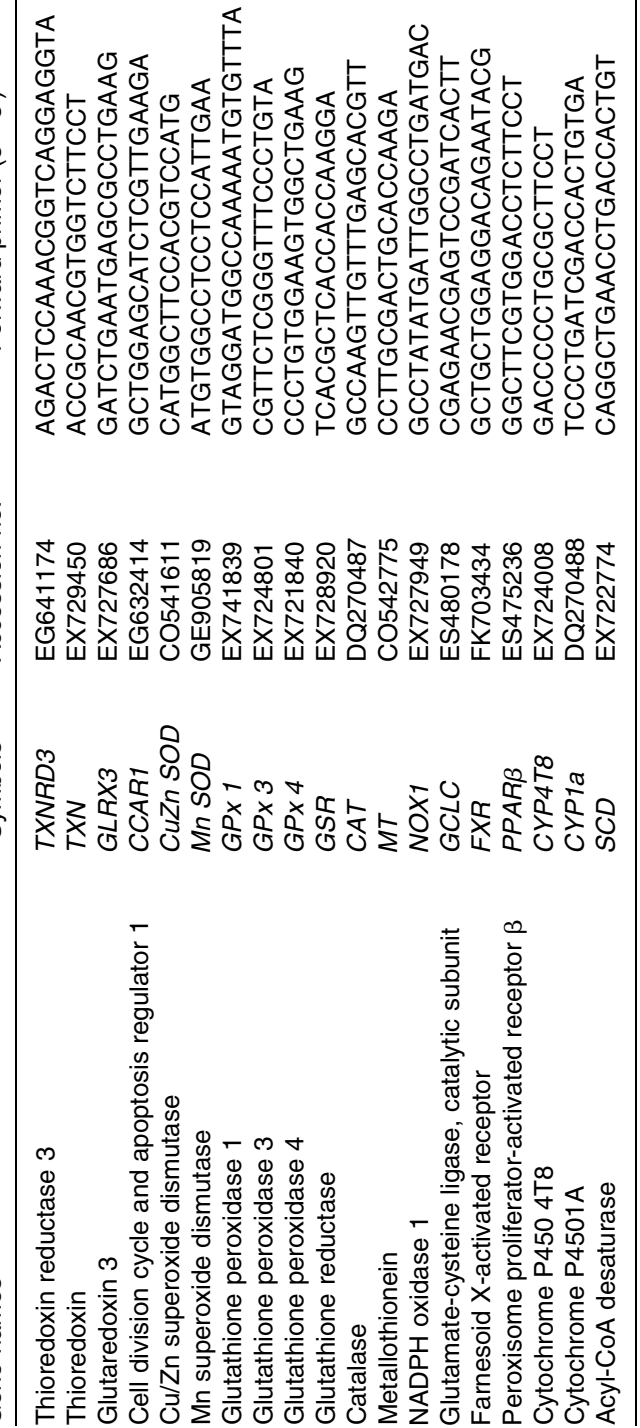

The assay uses 0.4 mm-4-nitrophenyl myristate, which serves as a substrate for most neutral lipases, in $25 \mathrm{~mm}$-ammonium bicarbonate, $0 \cdot 125 \mathrm{~m}$-sodium cholate, $37.5 \mathrm{~mm}-\mathrm{NaCl}, \mathrm{pH} 7 \cdot 8$, at $25^{\circ} \mathrm{C}$. Assays were done in ninety-six-well plates that were read every $15 \mathrm{~s}$ for $30 \mathrm{~min}$ at $404 \mathrm{~nm}$ with a microplate reader (iEMS Reader MF; Labsystems Oy).

The Cayman Chemical secretory PLA 2 assay kit (item no. 765001; Cayman Chemical Company) was used for enzyme activity calculations. The assay uses the 1,2-dithio analogue of diheptanoyl phosphatidylcholine (PC), which serves as a substrate for most $\mathrm{PLA}_{2}$ with the exception of cytosolic $\mathrm{PLA}_{2}{ }^{(23,24)}$. Upon hydrolysis of the thio ester bond at the sn-2 position by $\mathrm{PLA}_{2}$, free thiols are detected using 5,5'-dithio-bis-(2-nitrobenzoic acid). Plates were read every $15 \mathrm{~s}$ for $30 \mathrm{~min}$ at $414 \mathrm{~nm}$ with a microplate reader (iEMS Reader MF).

\section{Reduced glutathione and oxidised glutathione}

The microplate assay for reduced glutathione/oxidised glutathione (Oxford Biomedical Research) was used according to the manufacturer's instructions. Larvae (four to five from $45 \mathrm{dph}$ or two to three from $60 \mathrm{dph}$ ) were pooled before homogenisation. The pyridine derivate, serving as a thiolscavenging reagent, was added before homogenisation of larvae in the assay buffer.

\section{Thiobarbituric acid-reactive substances}

This analysis was performed according to Hamre et al. ${ }^{(25)}$. In short, lipid was removed from samples with the Bligh and Dyer extraction. An aliquot from the methanol/water phase was added to thiobarbituric acid in excess; when heated, malondialdehyde reacts with thiobarbituric acid and forms a coloured complex. The reaction is measured with a spectrophotometer at $532 \mathrm{~nm}$ and quantified by comparison with a standard.

\section{Histology}

Fixed specimens were embedded in resin (Technovit 7100). Then, $2 \mu \mathrm{m}$ sections in the longitudinal direction were made of the whole specimens and stained with borax-buffered toluidine blue. The sections were photographed using an Olympus BX51 microscope (Olympus) with a Nikon DS Fi1 camera (Nikon Instruments).

\section{Statistical analysis}

Potential differences were tested with one-way ANOVA. Fisher's least significant difference post hoc test was used to identify significant differences between group means. Differences and effects were considered significant at $P<0.05$, and all tests and differences were annotated with unlike letters in figures. ANOVA and post hoc analyses were performed on Statistica 10.0 (StatSoft, Inc.). Data are presented as means and standard deviations. 


\section{Results}

\section{Diets and fish larvae}

All diets contained equal concentrations of the analysed nutrients; with 44.1 (SD 0.3) \% protein, 16.9 (SD 0.8) \% lipid and 38.9 (SD 1.0 ) \% carbohydrate in DM and ash, and had $70 \cdot 1$ (SD 0.6) \% DM. There was no difference in thiobarbituric acid-reactive substances levels between the diets, with an average level of 46.7 (sD 8.4$) \mathrm{nmol} / \mathrm{g}$ wet weight. Due to the immediate change from rotifers to the formulated diets, there was a period of low feed intake in all diet groups that increased mortality and delayed growth. There was no observed cannibalism during the trial. This abrupt diet switch without co-feeding was done to avoid a situation where the fish larvae could selectively feed on rotifers, thus introducing the uncertainty about different preferences between the diets. The standard length of the larvae was $8.3(\mathrm{SD} 0.5) \mathrm{mm}$ at the start of the trial. During the following $15 \mathrm{~d}$, it increased to an average of 9.6 (SD 1.5) $\mathrm{mm}$ to reach 15.7 (SD 3.2) $\mathrm{mm}$ at the end of the trial. Growth data demonstrate that energy accumulation was the same in all diet groups. There were no differences in lengthwise growth between the treatments, but fish given the control diet (diet 1) were heavier than the other groups at mid-trial. However, this difference disappeared at the end of the trial (Table 4). There were no larvae left in the groups fed diet 6 at the final sampling due to high mortality. Mortality increased with increasing levels of NEFA in the diets with a correlation of $R^{2} 0.78$ (Fig. 1). The correlation between lyso-PL and mortality was $R^{2} 0.59$.

\section{Lipids}

There were differences in lipid levels between larvae fed the different diets after $15 \mathrm{~d}(45 \mathrm{dph})$, but these differences had disappeared after $30 \mathrm{~d}(60 \mathrm{dph})$. The $45 \mathrm{dph}$ larvae fed diet 2 had higher neutral lipids (12.0 (SD 0.4$) \mathrm{mg} / \mathrm{g}$ wet weight) compared with those fed diets 1,3 and 4 (9.6 (SD 0.9) $\mathrm{mg} / \mathrm{g}$ wet weight). Larvae fed diet 5 had lowest neutral lipids with a content of $7 \cdot 1$ (SD 0.9) $\mathrm{mg} / \mathrm{g}$ wet weight $(P<0 \cdot 05$, one-way

Table 4. Growth of fish larvae fed diets 1-6, after $15 d$ ( $45 \mathrm{~d}$ post-hatch (dph)) and $30 \mathrm{~d}$ (60 dph)

(Mean values and standard deviations, $n$ 20)

\begin{tabular}{|c|c|c|c|c|c|}
\hline \multirow[b]{2}{*}{ Age (dph) } & \multirow[b]{2}{*}{ Diets } & \multicolumn{2}{|c|}{ WW (mg) } & \multicolumn{2}{|c|}{$\mathrm{SL}(\mathrm{mm})$} \\
\hline & & Mean & SD & Mean & SD \\
\hline 45 & 1 & $11 \cdot 6^{\star}$ & $1 \cdot 2$ & $9 \cdot 6$ & 0.9 \\
\hline 45 & 2 & 8.9 & 0.2 & $9 \cdot 8$ & 0.9 \\
\hline 45 & 3 & 8.7 & $1 \cdot 1$ & $9 \cdot 8$ & 0.4 \\
\hline 45 & 4 & $9 \cdot 3$ & $1 \cdot 3$ & 9.9 & 0.5 \\
\hline 45 & 5 & 7.9 & $1 \cdot 1$ & $9 \cdot 3$ & 0.7 \\
\hline 45 & 6 & $7 \cdot 7$ & $1 \cdot 2$ & $9 \cdot 1$ & 0.6 \\
\hline 60 & 1 & $26 \cdot 3$ & $2 \cdot 8$ & $16 \cdot 1$ & 1.4 \\
\hline 60 & 2 & $25 \cdot 3$ & $3 \cdot 0$ & $15 \cdot 9$ & 0.9 \\
\hline 60 & 3 & $26 \cdot 5$ & 3.0 & $14 \cdot 9$ & 0.8 \\
\hline 60 & 4 & $22 \cdot 8$ & $2 \cdot 2$ & $16 \cdot 7$ & $3 \cdot 2$ \\
\hline 60 & 5 & $25 \cdot 8$ & $5 \cdot 0$ & $16 \cdot 0$ & 1.0 \\
\hline
\end{tabular}

WW, wet weight; SL, standard length.

${ }^{*}$ Mean value was significantly different from those of the other diet groups $(P<0.05$; ANOVA).

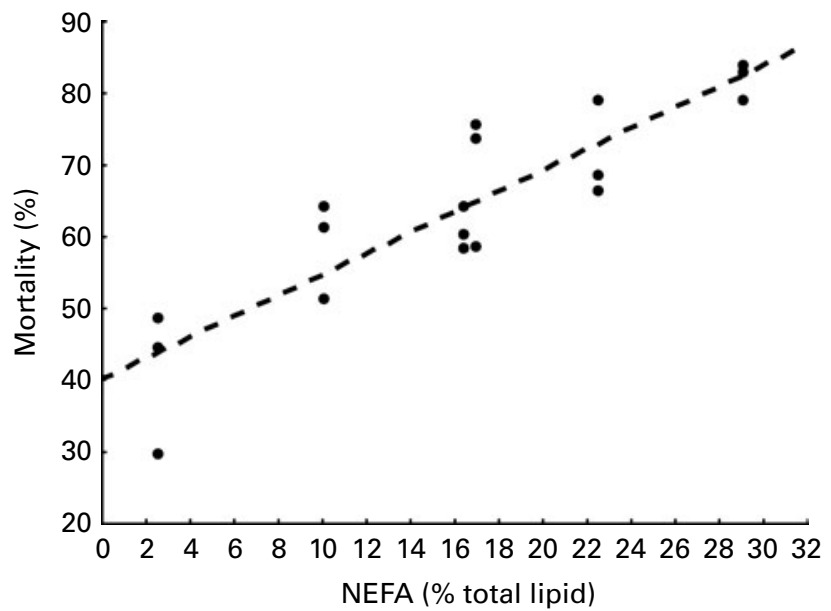

Fig. 1. Correlation between NEFA in the diets and cumulative mortality per experimental unit $\left(P<0.000 ; R^{2} 0.8, n 18\right)$.

ANOVA; Fig. 2). At the end of the trial, there were no differences in lipid levels between the groups (average for all groups: 15.2 (SD 2.5) mg/g dry weight). Polar lipid levels were 22.7 (SD 1.8) $\mathrm{mg} / \mathrm{g}$ wet weight for diet groups $1,2,3$ and 4 and decreased to $7 \cdot 1$ (SD $0 \cdot 9) \mathrm{mg} / \mathrm{g}$ wet weight in larvae fed diet $5(P<0.05$, one-way ANOVA; Fig. 2) at $45 \mathrm{dph}$. At the end of the trial, the polar lipid level increased to 25.7 ( $\mathrm{SD} \mathrm{3.3)} \mathrm{mg/g} \mathrm{wet} \mathrm{weight} \mathrm{for} \mathrm{larvae} \mathrm{fed} \mathrm{diets} \mathrm{1-5.}$ Due to low survival in larvae fed diet 6, only larvae from one tank were analysed at day 15 . These larvae contained $16.82 \mathrm{mg} / \mathrm{g}$ wet weight of polar lipids and $8.34 \mathrm{mg} / \mathrm{g}$ wet weight of neutral lipids. The most abundant PL, PC and phosphatidylethanolamine (PE), showed the same quantity distribution between the diet groups as seen in the total polar lipids, as did cardiolipin (Fig. 2). However, phosphatidylserine (PS) and phosphatidylinositol (PI) were lower in the diet 3 group than the diet 1, 2 and 4 groups (Fig. 2). TAG was higher in the diet 2 group than in the diet 1,3 and 4 groups, whereas the diet 5 group was lowest (Fig. 2).

\section{Enzyme activity}

Neutral lipase activity in whole fish was 0.113 (SD 0.032) $\mu \mathrm{mol} /$ min per g at $45 \mathrm{dph}$ and $0.132(\mathrm{SD} 0.019) \mu \mathrm{mol} / \mathrm{min}$ per $\mathrm{g}$ at $60 \mathrm{dph}$. PLA 2 activity was $0.037(\mathrm{SD} 0.014) \mu \mathrm{mol} / \mathrm{min}$ per $\mathrm{g}$ at $45 \mathrm{dph}$ and 0.029 (SD 0.012$) \mu \mathrm{mol} / \mathrm{min}$ per g at $60 \mathrm{dph}$. There were no effects of the diets on the enzymatic activity.

\section{Lipid metabolism and oxidative stress}

Larval mRNA levels of PPAR $\beta$ and cytochrome P450 4 and 1A (CYP4 and CYP1A) did not vary significantly between the diet groups at mid-trial or at the end of the trial. Farnesoid $X$ receptor $(F X R)$ mRNA was stable between the diet groups at mid-trial but at the end of the experiment, mRNA levels were elevated in larvae fed diets 2 and 3 compared with diets 1, 4 and 5. A similar pattern was seen in mRNA levels of stearoyl-CoA desaturase (SCD; Table 5). 
Table 5. Overview of the genes analysed, their function and the $P$ value of quantitative PCR analysis (one way-ANOVA)

\begin{tabular}{|c|c|c|}
\hline Symbols & Function & $P$ \\
\hline TXNRD3 & $\begin{array}{l}\text { Catalyses the reduction of thioredoxin, } \\
\text { and involves in the defence against } \\
\text { oxidative stress }\end{array}$ & 0.30 \\
\hline$T X N$ & $\begin{array}{l}\text { Acts as antioxidants by facilitating the } \\
\text { reduction of other proteins by cysteine }\end{array}$ & 0.24 \\
\hline GLRX3 & $\begin{array}{l}\text { Oxidoreductase reduces a variety of } \\
\text { substrates using glutathione as a } \\
\text { cofactor. May inhibit apoptosis }\end{array}$ & 0.23 \\
\hline CCAR1 & $\begin{array}{l}\text { Participates in cell-cycle progression } \\
\text { and/or cell proliferation. Associated with } \\
\text { apoptosis signalling }\end{array}$ & 0.26 \\
\hline CuZn SOD & $\begin{array}{l}\text { Cytoplasm. Destroys radicals which are } \\
\text { normally produced within the cells and } \\
\text { which are toxic to biological systems }\end{array}$ & 0.59 \\
\hline$M n S O D$ & $\begin{array}{l}\text { Mitochondrial. Destroys radicals which } \\
\text { are normally produced within the cells } \\
\text { and which are toxic to biological systems }\end{array}$ & 0.43 \\
\hline$G P \times 1$ & $\begin{array}{l}\text { Protects cells from oxidative breakdown. } \\
\text { It is the most abundantly expressed } \\
\text { GPX enzyme }\end{array}$ & 0.54 \\
\hline$G P \times 3$ & $\begin{array}{l}\text { Catalyses the reduction of } \mathrm{H}_{2} \mathrm{O}_{2} \text {, lipid } \\
\text { peroxides and organic } \mathrm{H}_{2} \mathrm{O}_{2} \text {, by } \\
\text { glutathione }\end{array}$ & 0.04 \\
\hline$G P \times 4$ & $\begin{array}{l}\text { Protects cells against membrane lipid } \\
\text { peroxidation and cell death, and } \\
\text { ingested lipid } \mathrm{H}_{2} \mathrm{O}_{2}\end{array}$ & 0.25 \\
\hline GSR & $\begin{array}{l}\text { Reduces glutathione disulphide (GSSG) } \\
\text { to the sulfhydryl form GSH, which is an } \\
\text { important cellular antioxidant }\end{array}$ & 0.52 \\
\hline$C A T$ & Protects cells from the toxic effects of $\mathrm{H}_{2} \mathrm{O}_{2}$ & 0.15 \\
\hline$M T$ & $\begin{array}{l}\text { Binds various metals; these proteins are } \\
\text { transcriptionally regulated by both heavy } \\
\text { metals and glucocorticoids }\end{array}$ & 0.52 \\
\hline$N O X 1$ & $\begin{array}{l}\text { Voltage-gated proton (hydrogen) channels } \\
\text { play an important role in cellular } \\
\text { defence against acidic stress. } \\
\text { Generates ROS }\end{array}$ & 0.14 \\
\hline GCLC & $\begin{array}{l}\text { First rate-limiting enzyme of glutathione } \\
\text { synthesis }\end{array}$ & 0.19 \\
\hline$F X R$ & $\begin{array}{l}\text { Has a vital function in bile acid } \\
\text { homeostasis }\end{array}$ & 0.02 \\
\hline PPAR & $\begin{array}{l}\text { Regulates gut development, fatty acid } \\
\text { oxidation, control of cell proliferation } \\
\text { and differentiation and tissue repair }\end{array}$ & 0.27 \\
\hline СУР 4Т8 & $\begin{array}{l}\text { Associated with the detoxification process, } \\
\text { reducing accumulated intracellular NEFA }\end{array}$ & 0.09 \\
\hline CYP1a & $\begin{array}{l}\text { Oxidises a variety of structurally unrelated } \\
\text { compounds, including steroids, fatty } \\
\text { acids and xenobiotics }\end{array}$ & 0.50 \\
\hline$S C D$ & $\begin{array}{l}\text { Catalyses a rate-limiting step in the } \\
\text { synthesis of unsaturated fatty acids }\end{array}$ & 0.03 \\
\hline
\end{tabular}

GPX, glutathione peroxidase; GSSG, oxidised glutathione; GSH, reduced glutathione; ROS, reactive oxygen species.

There were no differences in the levels of reduced glutathione or oxidised glutathione in larvae fed the different diets. Reduced glutathione was 474 (SD 73) $\mu \mathrm{m}$ in $45 \mathrm{dph}$ larvae and 599.9 (SD 108.2) $\mu \mathrm{m}$ in $60 \mathrm{dph}$ larvae. Oxidised glutathione was $2 \cdot 2(\mathrm{SD} 0.8)$ and $2.5(\mathrm{SD} 1.8) \mu \mathrm{M}$ in 45 and $60 \mathrm{dph}$ larvae, respectively. mRNA levels of thioredoxin reductase (TXNRD3), CuZn superoxide dismutases ( CuZn SOD), Mn superoxide dismutases ( $M n S O D$ ), glutathione peroxidase 1 and 4 (GPX 1 and 4), glutathione reductase (GSR), catalase $(C A T)$, thioredoxin $(T X N)$, metallothionein $(M T), \mathrm{NADPH}$ oxidase 1 (NOX1), glutaredoxin 3 (GLRX3), glutamatecysteine ligase $(G C L C)$ or cell division cycle and apoptosis regulator 1 (CCAR1) were similar in all diet groups (Table 5), both at 45 and $60 \mathrm{dph}$. However, glutathione peroxidase 3 (GPx 3) mRNA was lower in larvae fed diet 5 compared with those fed diet 3 at 60 dph (Fig. 3).

\section{Lipid-induced injury on enterocytes}

After $15 \mathrm{~d}$ on the trial diets, the presence of lipid vacuoles (droplets) in the enterocytes was similar in fish given diets 1-3. In fish larvae fed diets 4 and 5, lipid vacuoles had increased in numbers and started to merge. In fish given diet 6, the enterocytes were completely destroyed (Fig. 4). At the end of the trial, severe injury on the intestinal epithelium, such as rupture of the cell membrane of the enterocytes, was observed in fish larvae given all the different diets except the control diet (Fig. 4). The severity of intestinal injuries was amplified with the increasing amount of NEFA in the diets.

\section{Discussion}

The quantity of the PL classes (PC, PE, PS, PI and cardiolipin) in fish fed diets with intact PL was all similar. In fish fed diets with hydrolysed PL, only the diet group with intact TAG was able to maintain the PL level at the same level as the diet groups being fed intact PL. There was a general trend that when fed hydrolysed PL, the larvae were dependent on intact TAG to maintain the PL levels. This means that NEFA in the diet was probably not available for the de novo synthesis of PL or the remodelling of lyso-PL. Our laboratory experiment has previously shown that when cod larvae were fed diets in which part of the dietary lipids were NEFA, nearly all of the NEFA was catabolised, thus not integrated into lipids to be stored in the body ${ }^{(26)}$. It has also been demonstrated in yeast that intact TAG, and not NEFA, is a vital source of FA in PL metabolism. In yeast strains without the ability to hydrolyse TAG, PL synthesis was severely affected $^{(27)}$. We have here demonstrated that the lack of dietary intact TAG affects the synthesis (de novo or remodelling) of PL, PC and PE. This might explain the lack of a positive effect on growth in larvae fed the low dietary levels of NEFA (e.g. diet 2).

Lipids are an important source of energy for cod larvae; $100 \%$ of absorbed lipids are catabolised until a threshold level of retention is reached. This threshold is lower for polar lipids than for neutral lipids ${ }^{(26)}$. Here we demonstrate that TAG retention in larvae is maintained in larvae given hydrolysed TAG as long as the PL fraction is intact. This implies that larvae maintain a minimum level of neutral lipids at the cost of other lipid classes which are important for growth. However, this is not reflected in PC or PE levels, but might explain the decrease in PS and PI in fish given diet 3 .

NEFA has cytotoxic effects ${ }^{(28)}$. This is avoided by incorporation into TAG for storage or into PL of cellular membranes. Another way of dealing with the hazard is degradation via 

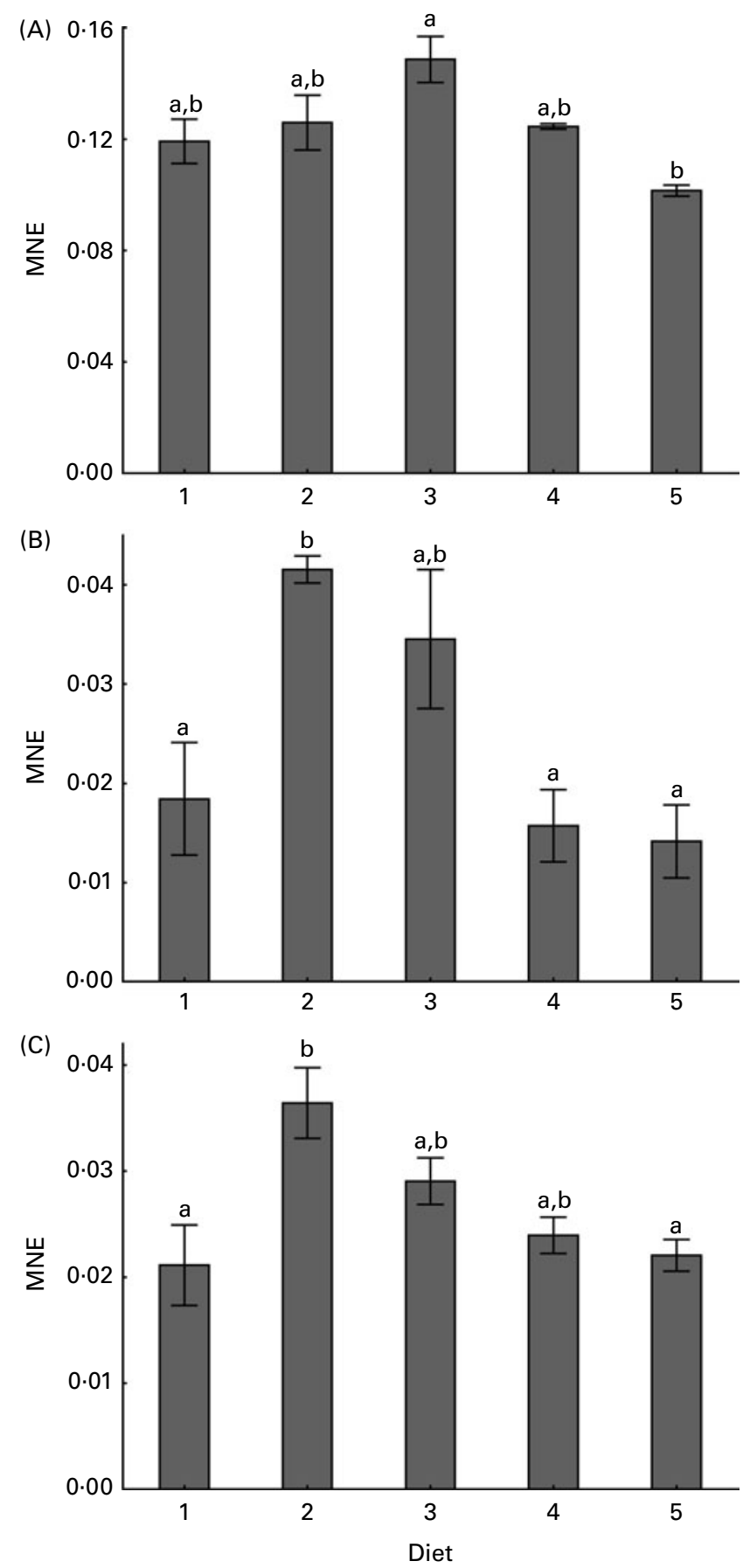

Fig. 3. Mean normalised expression (MNE) of the genes that responded to the trial diets after $30 \mathrm{~d}$. (A) Glutathione peroxidase $3(G P \times 3)$, (B) farnesoid $X$ receptor $(F X R)$ and $(C)$ stearoyl-CoA desaturase $(S C D)$. Values are means, with standard deviations represented by vertical bars. ${ }^{a, b}$ Mean values with unlike letters were significantly different $(P<0.05$; ANOVA).

$\alpha$-, $\beta$ - and $\omega$-oxidative pathways ${ }^{(29)}$. When $\beta$-oxidation is not sufficient for clearing the NEFA pool, the $\omega$-oxidative pathway becomes important ${ }^{(30)}$. The Cyp4 family is associated with the $\omega$-oxidative pathway ${ }^{(31)}$. However, this system seemed not to be affected when larvae were fed diets with increasing levels of NEFA. Other genes associated with toxic levels of NEFA and FA homeostasis such as $S C D^{(32,33)}$ and $F X R^{(34,35)}$ were up-regulated in larvae fed diets with partly hydrolysed TAG and intact PL. Fish given diets in which PL was hydrolysed did not induce a regulation different from the control diet. It is uncertain why the diets with the most NEFA did not lead to an up-regulation of FA homeostasis regulating genes while the moderately hydrolysed diets did. A possibility is that the intestinal epithelium was so damaged by the diets with hydrolysed PL that NEFA uptake was severely compromised at this point.

Cahu et $a l .^{(36)}$ demonstrated that the ratio of TAG and PL modulated the gene expression of BAL as well as the total neutral lipase enzymatic activity in sea bass (Dicentrarchus labrax) larvae. Genetic and enzymatic expression was modulated by dietary lipids as well. The diets of the present study varied in intact TAG:PL ratios, but this had no effect on the enzymatic activity of neutral lipases or phospholipases. This is similar to the findings of Morais et al. ${ }^{(37)}$ who did not find any effects of dietary lipid levels on mRNA levels or the activity of neutral lipases in sea bass (D. labrax) larvae. A possible explanation of the apparent inconsistency of these studies is the large difference in larval growth in the study of Cahu et al. ${ }^{(36)}$, compared with the study of Morais et $a l^{(37)}$ and the present one. When fish larvae are analysed according to age and not size, different developmental stages may be compared ${ }^{(38)}$.

Lipid-induced injury on the intestinal epithelium in fish has previously been reported in fish fed diets high in TAG and low in $\mathrm{PL}^{(39,40)}$. These injuries were attributed to steatosis due to the accumulation of lipid droplets in the enterocytes. The accumulation is thought to be caused by the need of dietary PL to assemble lipids in chylomicrons and VLDL for lipid transport from the intestine to peripheral tissues. Lipid accumulation in intestinal tissue due to high dietary TAG:PL ratios has been described in a wide range of fish species ${ }^{(39-47)}$. The injuries found in the present study were not caused by a high TAG:PL ratio, but bear the same characteristics. If intact dietary PL were an important factor in injuries, and consequent mortality, in the present study, there should have been a marked difference in injury and mortality between the diets with intact PL and those with hydrolysed PL, e.g. fish fed diet $3 v$. fish fed diet 4 . This was not the case. Instead, the degree of intestinal injury and mortality was correlated with the amount of NEFA in the diets. However, the toxic effect of NEFA did not affect growth measurements during the trial period. This indicates that dietary NEFA had a more toxic effect on larvae with poor growth than the more fit larvae. Similar findings have been found in red sea bream (Pagrus major) larvae where different groups exposed to increasing levels of $\mathrm{Zn}$ had increasing mortality from 0 to almost $100 \%$. The increasing $\mathrm{Zn}$ exposure did not influence the length of the surviving fish larvae ${ }^{(48)}$.

Lyso-PL may perturb membrane homeostasis and increase membrane fluidity and permeability ${ }^{(49)}$. Sawai et al. ${ }^{(50)}$ demonstrated that lyso-PC produced by $\mathrm{PLA}_{2}$ activity increased bacterial translocation as well as decreased transepithelial electrical resistance over the membrane. This did not occur when PL species other than PC were hydrolysed. NEFA alone did not affect bacterial translocation, but did 


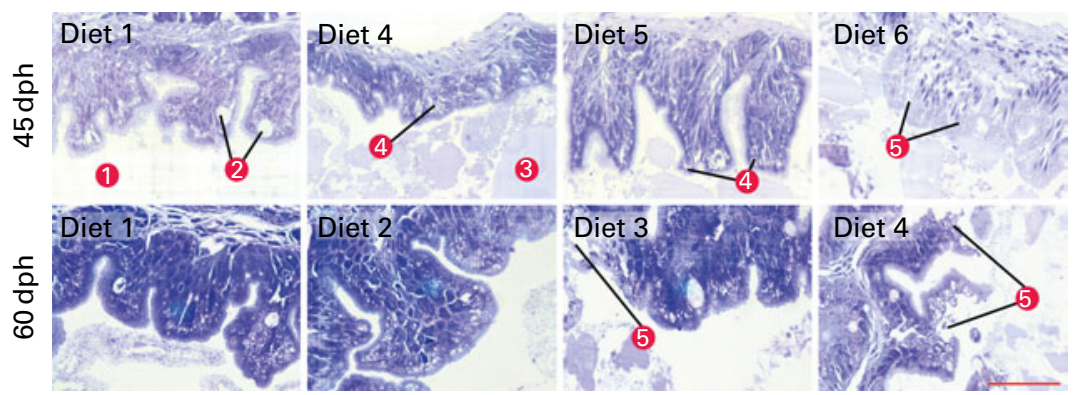

Fig. 4. Histology of the intestinal mucosa at mid-trial ( $45 \mathrm{~d}$ post-hatch $(\mathrm{dph}))$ and at the end of the trial $(60 \mathrm{dph}) .1$, Intestinal lumen; 2 , mucosal goblet cells; 3 , food particles in the lumen; 4, lipid droplets in enterocytes; 5, lysed epithelium. Scale bar, $50 \mu \mathrm{m}$ (A colour version of this figure can be found online at http://www.journals.cambridge.org/bjn).

decrease transepithelial electrical resistance in Caco-2 cells. The present results do not point towards lyso-PL as being the cause of death, indicating that membrane translocation of bacteria in the enterocytes has not been a problem. Decreased transepithelial electrical resistance, however, would be a challenge for the animal's osmoregulation.

The accumulative effect of dietary NEFA on the intestinal tissue of Atlantic cod larvae was similar to that found in mice given ricinoleic acid (the main toxic component in castor oil). In these mice, ricinoleic acid led to the exfoliation of enterocytes, exposing the subepithelial tissue to bacteria ${ }^{(51)}$. Similar exfoliation or degradation of enterocytes was observed in the present trial, in fish larvae fed diets with $2 \cdot 7 \%$ NEFA (diet 3) or more. It is thus possible that mortality was due to infections and/or osmotic stress due to the exposure of the subepithelial tissue.

Degradation of the intestinal epithelial tissue is therefore probably caused by NEFA. Lapre et al. ${ }^{(52)}$ demonstrated that NEFA with a carbon chain length of ten (C10) or more had a lytic effect on cells. Unsaturated FA were more lytic than SFA, but there were no differences between $18: 1$ and $18: 2$. The authors also demonstrated that the cytolytic effect of NEFA on Caco-2 cells was similar to the effect on erythrocytes, indicating that the lytic effect is not cell dependent. Other studies have shown endotheloid cells to be more resistant to NEFA than muscle cells. Endotheloid cells were lysed by 16:0 and longer FA after $36 \mathrm{~h}$ exposure, whereas muscle cells were also lysed by $14: 0^{(53)}$. When exposed to longer unsaturated FA (18:1, 18:2, 18:3 and 20:4), endotheloid cells were lysed by $20: 4$ after $4 \mathrm{~h}$ but not by shorter FA. Muscle cells, on the other hand, were vulnerable to both 18:3 and 20:4 after $2-4 \mathrm{~h}$ exposure ${ }^{(54)}$. Considering these effects on cells in culture, it is quite probable that chronic exposure to NEFA through the diet was a strain on the epithelia of the gut. Even though enterocytes are naturally exposed to NEFA during any meal, the exposure is controlled by the rate of hydrolysis by the digestive enzymes BAL and $\mathrm{PLA}_{2}$. The concentration of NEFA in the unstirred water layer is therefore manageable for the cell membrane to absorb (Fig. 5(A)). If the concentration of NEFA in the unstirred water layer is increased, the passive association of NEFA with the plasma membrane will increase accordingly. This may lead to destabilisation of the membrane as illustrated in Fig. 5(B).

There are very few in vivo studies on the effect of dietary NEFA; however, Velasquez et $a l^{(14)}$ found a similar effect in newborn piglet intestines to those described in Caco-2 cells and enterocytes. 8:0 FA gave fewer injuries than 10:0, 12:0 and 16:0.18:1 proved to be more harmful than shorter FA
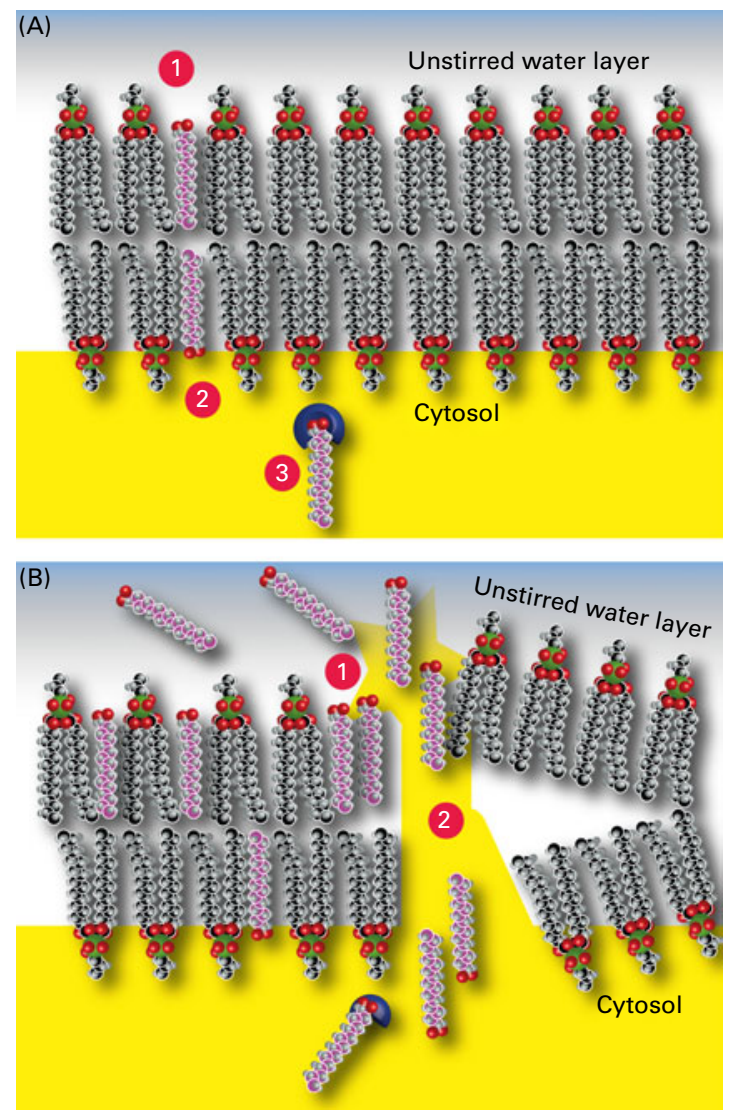

Fig. 5. Proposed cause of membrane disruption and subsequent exfoliation of enterocytes. (A) Transbilayer diffusion (flip-flop): 1, NEFA enters the outer leaflet of the cell membrane; 2, NEFA is transferred to the inner leaflet; 3 , NEFA enters the cytosol bound to fatty acid-binding protein. (B) Overload of NEFA in the bilayer: 1, a large number of NEFA enter the cell membrane; 2 , the membrane is destabilised and the cell lyses (A colour version of this figure can be found online at http://www.journals.cambridge.org/bjn). 
but not 18:3. They also found that 1 -d-old piglets were more sensitive to lipid-induced mucosal injury than 1-month-old piglets. This might also be true for fish such as Atlantic cod. For example, there are reports of experiments where adult Atlantic cod have been fed diets with up to $3 \cdot 8 \%$ NEFA without increased mortality ${ }^{(55)}$

In summary, we demonstrate the toxic effects of dietary NEFA on Atlantic cod larvae. Despite previous findings indicating a positive effect of dietary NEFA over periods of time counted in hours, we here demonstrate that over periods of days (15-30), dietary NEFA appear to be chronically toxic. Perhaps most surprisingly is the lack of a positive effect at low levels of dietary NEFA. The toxicity is probably not due to oxidative stress but to the lytic effect of NEFA on the intestinal epithelium.

\section{Acknowledgements}

This study is a part of the project financed by the Research Council of Norway: Ontogeny of lipid digestion and effects of feeding pre-digested lipids to Atlantic $\operatorname{cod}$ (G. morhua) larvae 179016/S40. We thank Samuel James Penglase for painstaking correction of the manuscript and for the valuable inputs. The contributions of the authors are as follows: A. N. and J. I. H. were responsible for the production of the experimental diets and lipid analysis. P. A. O. identified the genes analysed and designed the quantitative PCR primers. $\varnothing$. S. was the principal author, and performed the mRNA, protein, enzyme and histology analysis. T. H. ran the experiment. K. H. was the project leader and planned the study. All authors contributed to the writing of the manuscript. There are no conflicts of interest.

\section{References}

1. Vance DE \& Vance JE (2008) Biochemistry of Lipids, Lipoproteins and Membranes. Amsterdam: Elsevier.

2. Mansbach CM II, Tso P \& Kuksis A (2000) Intestinal Lipid Metabolism. New York, NY: Kluwer Academic/Plenum.

3. Brockman H (2001) Pancreatic lipase. In Intestinal Lipid Metabolism, pp. 61-73 [CM Mansbach, $\mathrm{P}$ Tso and A Kuksis, editors]. New York, NY: Kluwer Academic.

4. Lie O \& Lambertsen G (1985) Digestive lipolytic enzymes in cod (Gadus morbua) - fatty-acid specificity. Comp Biochem Physiol B Biochem Mol Biol 80, 447-450.

5. Sæle $\varnothing$, Nordgreen A, Olsvik PA, et al. (2010) Characterization and expression of digestive neutral lipases during ontogeny of Atlantic cod (Gadus morhua). Comp Biochem Physiol A Mol Integr Physiol 157, 252-259.

6. Uematsu K, Kitano M, Morita M, et al. (1992) Presence and ontogeny of intestinal and pancreatic phospholipase A2-like proteins in the Red sea bream, Pagrus major - an immunocytochemical study. Fish Physiol Biochem 9, 427-438.

7. Iijima N, Fujikawa Y, Tateishi Y, et al. (2001) Cloning and expression of group IB phospholipase $\mathrm{A}(2)$ isoforms in the red sea bream, Pagrus major. Lipids 36, 499-506.

8. Berton A, Sebban-Kreuzer C, Rouvellac S, et al. (2009) Individual and combined action of pancreatic lipase and pancreatic lipase-related proteins 1 and 2 on native versus homogenized milk fat globules. Mol Nutr Food Res 53, 1592-1602.

9. Miller R \& Lowe ME (2008) Carboxyl ester lipase from either mother's milk or the pancreas is required for efficient dietary triglyceride digestion in suckling mice. J Nutr 138, 927-930.

10. Darias MJ, Murray HM, Gallant JW, et al. (2007) The spatiotemporal expression pattern of trypsinogen and bile salt-activated lipase during the larval development of red porgy (Pagrus pagrus, Pisces, Sparidae). Mar Biol 152, 109-118.

11. Hernell O, Blackberg L, Chen Q, et al. (1993) Does the bile salt-stimulated lipase of human-milk have a role in the use of the milk long-chain polyunsaturated fatty-acids. $J$ Pediatr Gastroenterol Nutr 16, 426-431.

12. Hoehne-Reitan K, Kjorsvik E \& Reitan KI (2001) Bile saltdependent lipase in larval turbot, as influenced by density and lipid content of fed prey. J Fish Biol 58, 746-754.

13. Mollan TA, Tonheim SK \& Hamre K (2008) Pre-hydrolysis improves absorption of neutral lipids in Atlantic halibut (Hippoglossus bippoglossus, L.) larvae. Aquaculture $\mathbf{2 7 5}$, 217-224.

14. Velasquez OR, Tso P \& Crissinger KD (1993) Fatty acidinduced injury in developing piglet intestine - effect of degree of saturation and carbon-chain length. Pediatr Res 33, 543-547.

15. ChungGK \& YangLY (2004) Method for preparing lysophosphatidylethanolamine. Patent no. US 6.773.902 B1.

16. Henderson RJ \& Tocher DR (1992) Thin-layer chromatography. In Lipid Analysis. Practical Approach, pp. 65-111 [RJ Hamilton and S Hamilton, editors]. Oxford: IRL Press.

17. Lie O \& Lambertsen G (1991) Lipid digestion and absorption in cod (Gadus-Morhua), comparing triacylglycerols, wax esters and diacylalkylglycerols. Comp Biochem Physiol A Physiol 98, 159-163.

18. Mueller O, Hahnenberger K, Dittmann M, et al. (2000) A microfluidic system for high-speed reproducible DNA sizing and quantitation. Electrophoresis 21, 128-134.

19. Imbeaud S, Graudens E, Boulanger V, et al. (2005) Towards standardization of RNA quality assessment using user-independent classifiers of microcapillary electrophoresis traces. Nucleic Acids Res 33, e56.

20. Sæle $\varnothing$, Nordgreen A, Hamre K, et al. (2009) Evaluation of candidate reference genes in Q-PCR studies of Atlantic cod (Gadus morbua) ontogeny, with emphasis on the gastrointestinal tract. Comp Biochem Physiol B Biochem Mol Biol 152, 94-101.

21. Vandesompele J, De Preter K, Pattyn F, et al. (2002) Accurate normalization of real-time quantitative RT-PCR data by geometric averaging of multiple internal control genes. Genome Biol 3, 0034.1.

22. Murray HM, Gallant JW, Perez-Casanova JC, et al. (2003) Ontogeny of lipase expression in winter flounder. J Fish Biol 62, 816-833.

23. Reynolds LJ, Hughes LL \& Dennis EA (1992) Analysis of human synovial-fluid phospholipase-A2 on short chain phosphatidylcholine-mixed micelles - development of a spectrophotometric assay suitable for a microtiterplate reader. Anal Biochem 204, 190-197.

24. Hendrickson HS, Hendrickson EK \& Dybvig RH (1983) Chiral synthesis of a dithiolester analog of phosphatidylcholine as a substrate for the assay of phospholipase-A2. J Lipid Res 24, 1532-1537.

25. Hamre K, Næess T, Espe M, et al. (2001) A formulated diet for Atlantic halibut (Hippoglossus hippoglossus, L.) larvae. Aquac Nutr 7, 123-132.

26. Hamre K, Lukram IM, Ronnestad I, et al. (2011) Pre-digestion of dietary lipids has only minor effects on absorption, 
retention and metabolism in larval stages of Atlantic cod (Gadus morhua). Br J Nutr 105, 846-856.

27. Rajakumari S, Rajasekharan R \& Daum G (2010) Triacylglycerol lipolysis is linked to sphingolipid and phospholipid metabolism of the yeast Saccharomyces cerevisiae. Biochim Biophys Acta Mol Cell Biol. Lipids 1801, 1314-1322.

28. Listenberger LL, Han XL, Lewis SE, et al. (2003) Triglyceride accumulation protects against fatty acid-induced lipotoxicity. Proc Natl Acad Sci U S A 100, 3077-3082.

29. Antony GJ \& Landau BR (1968) Relative contributions of alpha- beta- and omega-oxidative pathways to in vitro fatty acid oxidation in rat liver. J Lipid Res 9, 267-269.

30. Wanders RJA, Komen J \& Kemp S (2010) Fatty acid omega-oxidation as a rescue pathway for fatty acid oxidation disorders in humans. FEBS J 278, 182-194.

31. Adas F, Salaun JP, Berthou F, et al. (1999) Requirement for omega and (omega-1)-hydroxylations of fatty acids by human cytochromes P450 2E1 and 4A11. J Lipid Res 40, 1990-1997.

32. Ntambi JM (1999) Regulation of stearoyl-CoA desaturase by polyunsaturated fatty acids and cholesterol. J Lipid Res $\mathbf{4 0}$, 1549-1558.

33. Flowers MT \& Ntambi JM (2008) Role of stearoyl-coenzyme A desaturase in regulating lipid metabolism. Curr Opin Lipidol 19, 248-256.

34. Trauner M, Claudel T, Fickert P, et al. (2010) Bile acids as regulators of hepatic lipid and glucose metabolism. Dig Dis 28, 220-224.

35. Wang YD, Chen WD, Moore DD, et al. (2008) FXR: a metabolic regulator and cell protector. Cell Res 18, 1087-1095.

36. Cahu CL, Infante JLZ \& Barbosa V (2003) Effect of dietary phospholipid level and phospholipid: neutral lipid value on the development of sea bass (Dicentrarchus labrax) larvae fed a compound diet. Br J Nutr 90, 21-28.

37. Morais S, Cahu C, Zambonino-Infante JL, et al. (2004) Dietary TAG source and level affect performance and lipase expression in larval sea bass (Dicentrarchus labrax). Lipids 39, 449-458.

38. Saele O \& Pittman KA (2010) Looking closer at the determining of a phenotype? Compare by stages or size, not age. J Appl Ichthyol 26, 294-297.

39. Fontagne S, Geurden I, Escaffre AM, et al. (1998) Histological changes induced by dietary phospholipids in intestine and liver of common carp (Cyprinus carpio L.) larvae. Aquaculture 161, 213-223.

40. Deplano M, Connes R, Diaz JP, et al. (1989) Intestinal steatosis in the farm-reared sea bass (Dicentrarchus labrax). Dis Aquat Organ 6, 121-130.

41. Bergot P \& Fléchon JE (1970) Forme et voie d'absorption intestinale des acides gras chez la truitte arc-en-ciel (Salmo gairdneri Rich.). I. Lipides en particules (Form and route of intestinal absorption of fatty acids in the rainbow trout (Salmo gairdneri Rich.). I. Lipid particles). Annal Biol Anim Biochim Biophys 10, 459-472.
42. Bergot P \& Fléchon JE (1970) Forme et voie d'absorption intestinale des acides gras à chaine longue chez la truite arc-en-ciel (Salmo gairdneri Rich.). II. Lipides 'étalés' (Form and route of intestinal absorption of long-chain fatty acids in the rainbow trout (Salmo gairdneri Rich.). II. Lipid 'spread'). Annal Biol Anim Biochim Biophys 10, 473-480.

43. Vernier J \& Sire M (1983) L'absorption intestinale des lipides chez la truite arc-en-ciel (Salmo gairdneri) (The intestinal absorption of lipids in the rainbow trout (Salmo gairdneri)). Bases biologiques de l'aquaculture, Montpellier 1, 393-428.

44. Noaillac-Depeyre J \& Gas N (1979) Structure and function of the intestinal epithelial cells in the perch (Perca fluviatillis L.). Anat Rec 195, 621-627.

45. Noaillac-Depeyre J \& Gas N (1976) Electron microscopic study on gut epithelium of the tench (Tinca tinca L.) with respect to its absorptive functions. Tissue Cell 8, 511-530.

46. Noaillac-Depeyre J \& Gas N (1974) Fat absorption by the enterocytes of the carp (Cyprinus carpio L.). Cell Tissue Res 155, 353-365

47. Sarasquete MC, Polo A \& Yufera M (1995) Histology and histochemistry of the development of the digestive-system of larval gilthead seabream (Sparus aurata). Aquaculture 130, 79-92.

48. Huang W, Cao L, Shan XJ, et al. (2010) Toxic effects of zinc on the development, growth, and survival of red sea bream Pagrus major embryos and larvae. Arch Environ Contam Toxicol 58, 140-150.

49. Farooqui AA \& Horrocks LA (2006) Phospholipase A(2)-generated lipid mediators in the brain: the good, the bad, and the ugly. Neuroscientist 12, 245-260.

50. Sawai T, Drongowski RA, Lampman RW, et al. (2001) The effect of phospholipids and fatty acids on tight-junction permeability and bacterial translocation. Pediatr Surg Int 17, 269-274

51. Morehouse JL, Specian RD, Stewart JJ, et al. (1986) Translocation of indigenous bacteria from the gastrointestinal-tract of mice after oral ricinoleic acid treatment. Gastroenterology 91, 673-682.

52. Lapre JA, Termont D, Groen AK, et al. (1992) Lytic effects of mixed micelles of fatty-acids and bile-acids. Am J Physiol 263, G333-G337.

53. Wenzel DG \& Hale TW (1978) Toxicity of free fatty-acids for cultured rat-heart muscle and endothelioid cells. 1. Saturated long-chain fatty-acids. Toxicology 11, 109-117.

54. Wenzel DG \& Hale TW (1978) Toxicity of free fatty-acids for cultured rat-heart muscle and endothelioid cells. 2 . Unsaturated long-chain fatty-acids. Toxicology 11, 119-125.

55. Lie O, Lied E \& Lambertsen G (1987) Lipid digestion in cod (Gadus-Morhua). Comp Biochem Physiol B Biochem Mol Biol 88, 697-700.

56. Kvale A, Harboe T, Espe M, et al. (2002) Effect of predigested protein on growth and survival of Atlantic halibut larvae (Hippoglossus hippoglossus, L.). Aquaculture 33, $311-321$ 